\title{
Cooling Path Dependent Behavior of a Supersolvus Heat Treated Nickel Base Superalloy
}

\author{
R.D. Kissinger \\ GE Aircraft Engines, Cincinnati, OH 45215
}

\begin{abstract}
A key business initiative for jet engine manufactures is to reduce the engine development cycle time. Cycle time reductions lead to reduced introduction costs, and allow the manufacturer to get their product to market before their competitors. Two materials evaluation techniques are presented that allow for significant reductions in cost and time during the development of new turbine components. The on-cooling tensile test produces data that, when coupled with thermal/stress models, allows for the design of a forging shape and/or heat treatment parameters that preclude quench cracking and the accompanying manufacturing productivity losses. The two-step cooling path technique allows for the measurement of critical mechanical properties from small coupons, instead of heat treating and evaluating a full scale forging.
\end{abstract}

\section{Introduction}

The demand for improved efficiency of aircraft gas turbine engines by operating at higher compressor discharge temperatures has required an improvement in the creep capabilities of turbine disk alloys. Concurrently, disk alloys require improved resistance to fatigue crack growth to meet customers' residual life requirements, e.g. ENSIP (1). These demands have resulted in the development of powder metallurgy (PM) alloys which are solution heat treated above their gamma prime solvus temperatures to achieve a significantly coarser grain size as compared to PM alloys processed below their gamma prime solvus temperatures. Whilc the supersolvus solution heat treatment has been shown to improve both creep strength and fatigue crack growth resistance (2), it presents processing challenges which must be overcome, the most significant being the balance between producibility and mechanical properties. It is well known that the mechanical properties of solutioned and aged nickel base superalloy disks are dependent on the cooling path (instantaneous cooling rate and the shape of the cooling curve) through the gamma prime solvus. In general, faster cooling rates produce higher tensile and creep strengths; however, if cooling rates are too fast during the quench from the solution temperature, quench cracking will occur. This is especially true for supersolvus heat treated alloys, which experience higher thermal gradients and thermally induced surface stresses during quenching.

Rotating PM turbine components vary significantly in size and shape, and have different mechanical property requirements as dictated by function, e.g. disk bore, disk rim, or shaft. It would not be practical from a cost and timing perspective to perform full scale trials for each component in order to determine a heat treatment that produces adequate mechanical properties without quench cracking. Heat treatment process modeling offers the ability to determine heat treatment parameters quickly and cheaply provided the input data and failure criterion are accurate. It is the purpose of this paper to present experimental techniques and data that has allowed successful heat treatment modeling of full scale disk hardware for a recently developed PM disk alloy, Rene'88DT (2). This paper will not discuss the details of heat treatment models or the application of these models to the heat treatment of forgings; additional details can be found in cited references. It is believed that the methods and conclusions described herein would be applicable to other gamma prime strengthened nickel base alloys.

\section{On-cooling Tensile Tests}

A critical processing step in the manufacture of a Rene'88DT turbine disk is the quench from the supersolvus solution temperature. A minimum cooling rate is required to achieve acceptable mechanical properties; however, an excessively rapid quench may generate thermally induced stresses sufficient to cause catastrophic failure (quench cracking). Ideally, a finite element model would be able to define a disk geometry and quench medium which would achieve the desired cooling rate and properties without cracking. If a model is to be successful in predicting quench cracking, then a failure criterion must be defined which identifies a stress above which the material will crack. The on-cooling tensile test is an attempt to define this criterion.

The test consists of taking a standard tensile specimen $(0.25$ inch diameter by 1.36 inch gage length) and leating it to the solution temperature $\left(2100^{\circ} \mathrm{F}\right)$ which is above the gamma prime solvus of Rene' $88 \mathrm{DT}\left(2030^{\circ} \mathrm{F}\right)$. The specimen is then cooled at a controlled rate to a specified test temperature, stabilized for approximately one minute, and then pulled in tension to failure at an initial strain rate of $0.05 /$ minute. The $0.2 \%$ yield and ultimate tensile strengths are calculated from load vs. stroke curves.

The ultimate tensile strength (UTS) can be used as a failure criterion when attempting to predict quench cracking. For a given disk geometry, effective stresses can be calculated at specific locations as a function of decreasing temperature and plotted against the on-cooling data. If the local effective stress exceeds the measured UTS, there would be a high probability that the disk would crack at that location (3).

Turbine disks are usually heat treated horizontally on a support grate. Inherent to this procedure is a significantly different cooling rate on the top surface of the disk compared to the bottom surface. It would therefore be of interest to look at the effect of different cooling rates on on-cooling tensile properties. Two cooling rates have been investigated: $400^{\circ} \mathrm{F} /$ minute (bottom disk surface) and $2000^{\circ} \mathrm{F} /$ minute (top disk surface). These cooling rates were chosen based on data from near surface thermocouples (T/C's) embedded in a turbine disk (3).

\section{Two-Step Cooling Path}

A typical turbine disk solution heat treatment process can include a fan air cool (FAC) before the forging is oil quenched (3). The brief FAC reduces surface temperatures and thereby eliminates quench cracking because the surface material has gained sufficient strength to survive 


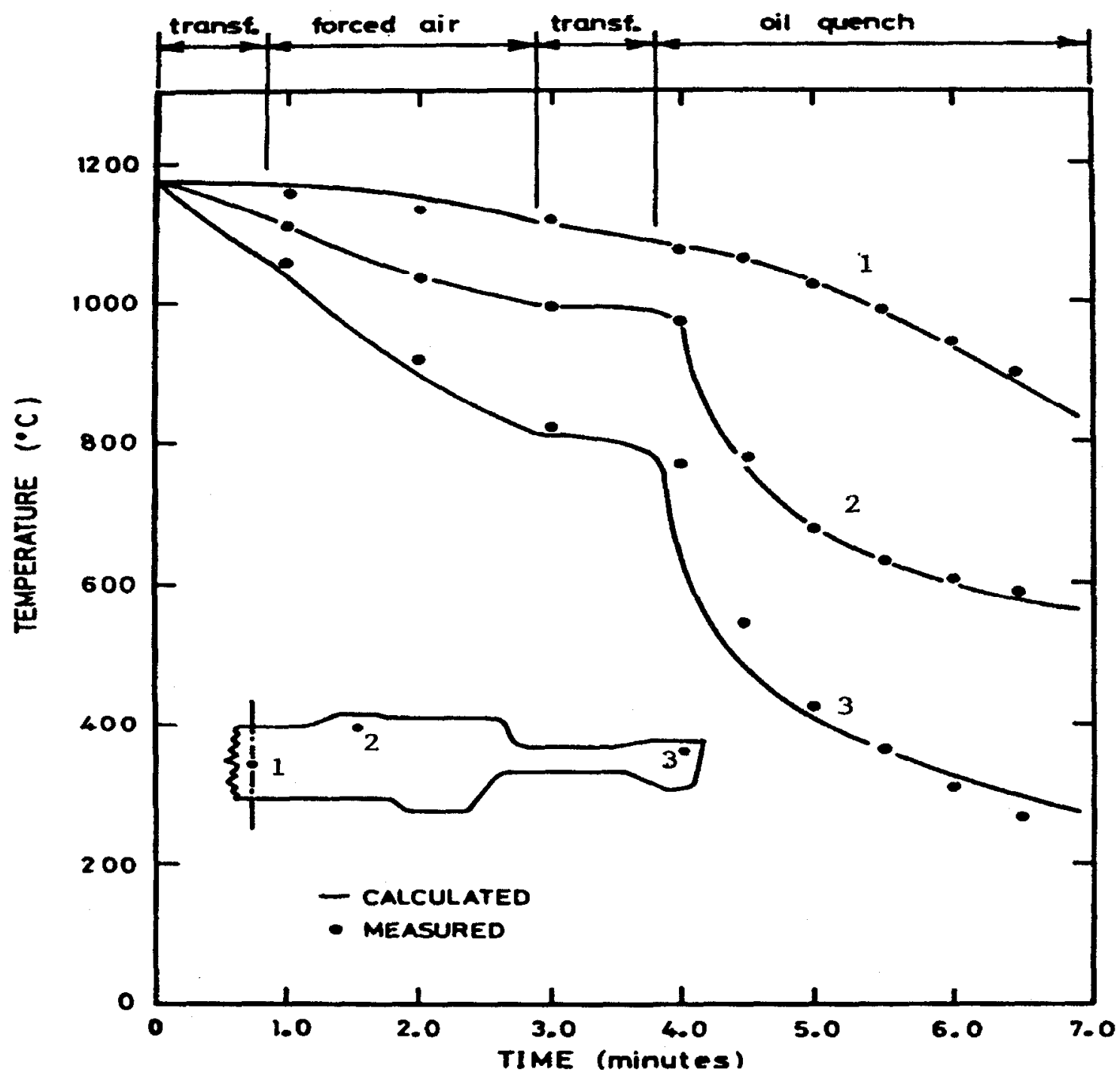

Figure 1. Typical cooling curves for different locations in a turbine disk (Ref. 3).

thermally induced stresses. The FAC segment produces a two-step cooling curve as shown in Figure 1. Depending on location, the FAC may produce a range of instantaneous cooling rates from $30^{\circ} \mathrm{F} /$ minute inthe bore (location 1), or $200^{\circ} \mathrm{F} /$ minute in the rim (location 3), of an turbine disk given a two minute FAC. The oil quench produces a bore cooling rate of $170^{\circ} \mathrm{F} /$ minute and a initial rim cooling rate of $800^{\circ} \mathrm{F} /$ minute. The transition temperature, i.e. knee in the cooling curve, between FAC and oil quench cooling rates is strongly dependent on location, ranging from $1920^{\circ} \mathrm{F}$ at location 1 to $1450^{\circ} \mathrm{F}$ at location 3 .

An experiment was designed to determine the effect of a two-step cooling curve on tensile, creep/rupture and fatigue crack growth (FCG) properties in the thicker sections of a large Rene'88DT forging. Cooling rate variables included slow $\left(7^{\circ} \mathrm{F} /\right.$ minute $)$ and fast $\left(30^{\circ} \mathrm{F} /\right.$ minute $)$ first step rates, a second step cooling rate of $360^{\circ} \mathrm{F} /$ minute, and $2000^{\circ} \mathrm{F}$ and $1900^{\circ} \mathrm{F}$ as locations of the transition temperature. The transition temperatures of $1900^{\circ} \mathrm{F}$ and $2000^{\circ} \mathrm{F}$ wete chosen to be close to, but lower than, the gamma prime solvus of Rene'88DT.

\section{Experimental Procedure}

\section{Material}

The material for this study was taken from a production Rene'88DT turbine disk in the solutioned $\left(2100^{\circ} \mathrm{F}\right.$ for one hour) and aged $\left(1400^{\circ} \mathrm{F}\right.$ for 8 hours) condition. Rene'88DT is a powder metallurgy alloy that was argon atomized, extrusion consolidated, isothermally forged, supersolvus heat treated and aged to produce a nominal ASTM 7-8 grain size (2). The alloy chemistry (in weight percent) is $56.5 \% \mathrm{Ni}, 16.0 \% \mathrm{Cr}, 12.7 \%$ $\mathrm{Co}, 4.0 \% \mathrm{Mo}, 4.0 \% \mathrm{~W}, 3.81 \% \mathrm{Ti}, 2.23 \% \mathrm{Al}, 0.7 \% \mathrm{Nb}, 0.043 \% \mathrm{C}$, $0.016 \% \mathrm{~B}$, and $0.05 \mathrm{Zr}$. 


\section{On-Cooling Tensile Test}

The on-cooling tensile test was developed at Metcut Research Associates, Inc. in support of a GE purchase order and statement of work (5). The test consisted of three segments. First, the tensile specimen ( 0.25 inch diameter and 1.3 inch gage length) was given a controlled heat-up to a pre-test, subsolvus soak temperature of $1900^{\circ} \mathrm{F}$, held for five minutes, and then heated at about $150^{\circ} \mathrm{F} /$ minute to $2100^{\circ} \mathrm{F}$, and held for five minutes. Second, the specimen gage was subjected to a controlled cooling rate of either $400^{\circ} \mathrm{F}$ or $2000^{\circ} \mathrm{F} /$ minute from $2100^{\circ} \mathrm{F}$ to the selected test temperature, and stabilized for about 60 seconds. Test temperatures were in the range of $1300-2100^{\circ} \mathrm{F}$. Finally, the specimen was pulled to failure on a 20,000 pound MTS closed loop servo controlled hydraulic system at a constant crosshead speed with an initial strain rate of $0.05 /$ minute. An Ameritherm induction unit was the heating source, and the heating/cooling cycle was controlled by a Wavetek Model 75 waveform generator. The $400^{\circ} \mathrm{F} /$ minute cooling rate required a controlled power reduction of the induction coil, while the $2000^{\circ} \mathrm{F} /$ minute cooling rate required a complete shut-down of power to the coil pius forced air cooling of the top and bottom grips and specimen shoulders. The cooling air was supplied by copper tubes.

Temperature control during the $1900^{\circ} \mathrm{F}$ preheat, $2100^{\circ} \mathrm{F}$ solution, and cool down was achieved using an Ircon pyrometer sampling the center gage location. To assure pyrometer accuracy, two tensile specimens were instrumented with surface and internal T/C's to compare readings. (For internal $\mathrm{T} / \mathrm{C}$ 's, the specimens were machined with a hole centered along the specimen axes, and a sheathed $T / C$ was inserted $s o$ as to read the temperature at the center of the gage length.) Testing procedures were established which assured accurate pyrometer temperature measurements of the specimen surface. Cooling rates were calculated from the average slope of the temperature vs. time plots as recorded from the pyrometer. After completion of the tensile testing, selected specimens were evaluated for grain size. Metallographic samples were taken from broken tensile specimens adjacent to the fracture surfaces or from the midsections of unfailed specimens. Optical and high resolution SEM micrographs were obtained from transverse surfaces.

\section{Two-Step Cooling Path}

Cooling Rates. Table I and Figure 2 summarize the various heat treatments evaluated. Cooling rates were calculated from T/C data obtained from a IN718 coupon with an embedded thermocouple (T/C). The $7^{\circ} \mathrm{F} /$ minute rate was obtained by air cooling the coupon in a ceramic jacket (hollow ceramic brick). The $30^{\circ} \mathrm{F} /$ minute rate was obtained by fan air cooling the coupon in a ccramic jacket. A standard shop floor fan was used. The $350^{\circ} \mathrm{F} /$ minute rate was obtained by fan air cooling the bare coupon after removing it from the ceramic jacket.

Heat Treatments. Jacketed Rene'88DT coupons were loaded into an air furnace. The coupons were stabilized at $1960^{\circ} \mathrm{F}$ before heating to $2100^{\circ} \mathrm{F}$. Jacketed coupons were removed and air cooled or fan air

Table I.

Two-Step Heat Treatment Parameters

\begin{tabular}{|c|c|c|c|}
\hline $\begin{array}{c}\text { Heat } \\
\text { Treatment }\end{array}$ & $\begin{array}{c}\text { First Step } \\
\text { Cooling Rate } \\
\text { ('F/minute) }\end{array}$ & $\begin{array}{c}\text { Second Step } \\
\text { Cooling Rate } \\
\text { ('F/minute) }\end{array}$ & $\begin{array}{c}\text { Transition } \\
\text { Temperature } \\
\text { ('F/minute) }\end{array}$ \\
\hline & & & \\
A & 30 & 350 & 2000 \\
B & 30 & 350 & 1900 \\
C & 7 & 350 & 2000 \\
D & 7 & 350 & 1900 \\
\hline
\end{tabular}

cooled for a specified time, as determined by the IN718 T/C data, to reach the transition temperaturc. At the prescribed time, the coupon was removed from the ceramic brick and FAC to room temperature. Following the solution heat treatment, the coupons were aged at $1400^{\circ} \mathrm{F}$ for 8 hours and air cooled.

Testing. Tensile and creep/rupture tests werc performcd using standard ASTM testing procedures. FCG tests were performed at GE Aircraft Engines using standard potential drop testing techniques. Test specimens had a rectangular cross section of 0.400 inch by 0.168 inch, and a gage length of 1.25 inch. $20 \mathrm{cpm}$ specimens (triangular wave form) at $750^{\circ} \mathrm{F}$ and $1200^{\circ} \mathrm{F}$ were EDM notched with a 5 mil x 10 mil surface flaw from which precracks were initiated. The notches were centered on one of the 0.400 inch faces, and specimens were precracked at $90 \mathrm{ksi} / 10 \mathrm{~Hz}$ at room temperature to a nominal 12 mil $\times 24$ mil crack before testing at elevated temperatures. The net section maximum stress for the $750^{\circ} \mathrm{F}$ tests was $125 \mathrm{ksi}$; for $1200^{\circ} \mathrm{F}$ it was $100 \mathrm{ksi} .1200^{\circ} \mathrm{F} / 90$ second hold time tests $(20 \mathrm{cpm}$ triangular wave form with a superimposed 90 second hold at the maximum stress of $100 \mathrm{ksi}$ ) used a 5 mil $\times 10$ mil EDM notch and were precracked at $90 \mathrm{ksi} / 10 \mathrm{~Hz}$ at room temperature to a nominal 15 mil $\times 30$ mil crack before testing at elevated temperature. Gage section temperatures for all FCG tests were controlled using tac welded T/C's located above one of the potential drop wires. All FCG tests used an R ratio of 0.05 .

\section{Experimental Results}

\section{On-Cooling Tensile Tests}

Averages of duplicate on-cooling UTS and percent elongation data from $400^{\circ} \mathrm{F} /$ minute and $2000^{\circ} \mathrm{F} /$ minute tests are plotted graphically in Figures 3 and 4., respectively. $400^{\circ} \mathrm{F} /$ minute tests showed variations in cooling rate from $368^{\circ} \mathrm{F}$ to $440^{\circ} \mathrm{F} / \mathrm{min} ; 2000^{\circ} \mathrm{F} /$ minute tests varied from $1463^{\circ} \mathrm{F}$ to $2084^{\circ} \mathrm{F} / \mathrm{min}$. Only four tests exceeded the one minute stabilization time beforc starting the test, with the longest time being 90 seconds. Grain sizes measured from selected specimens ranged from ASTM 6.8-9.5, except for $400^{\circ} \mathrm{F} /$ minute tests at 2075 and $2100^{\circ} \mathrm{F}$, where grain sizes were ASTM 5.5 and 3.0, respectively. High resolution SEM photos in Figure 5 compare gamma prime sizes as a function of cooling rate for tensile tests at $1500^{\circ} \mathrm{F}$. For the $1500^{\circ} \mathrm{F}$ test, cooling rate significantly affected gamma prime size. The $400^{\circ} \mathrm{F} /$ minute cooling rate produced gamma prime precipitates that were approximately $0.1 \mu \mathrm{m}$ in diameter; the $2000^{\circ} \mathrm{F} /$ minute coolin g rate produced $0.03 \mu \mathrm{m}$ diameter

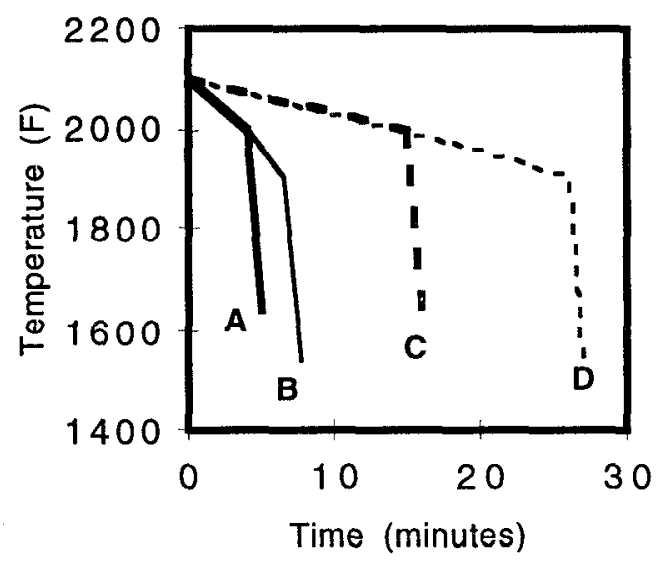

Figure. 2. Two-step cooling curves. 
Figure 3. On-Cooling Tensile UTS and YS

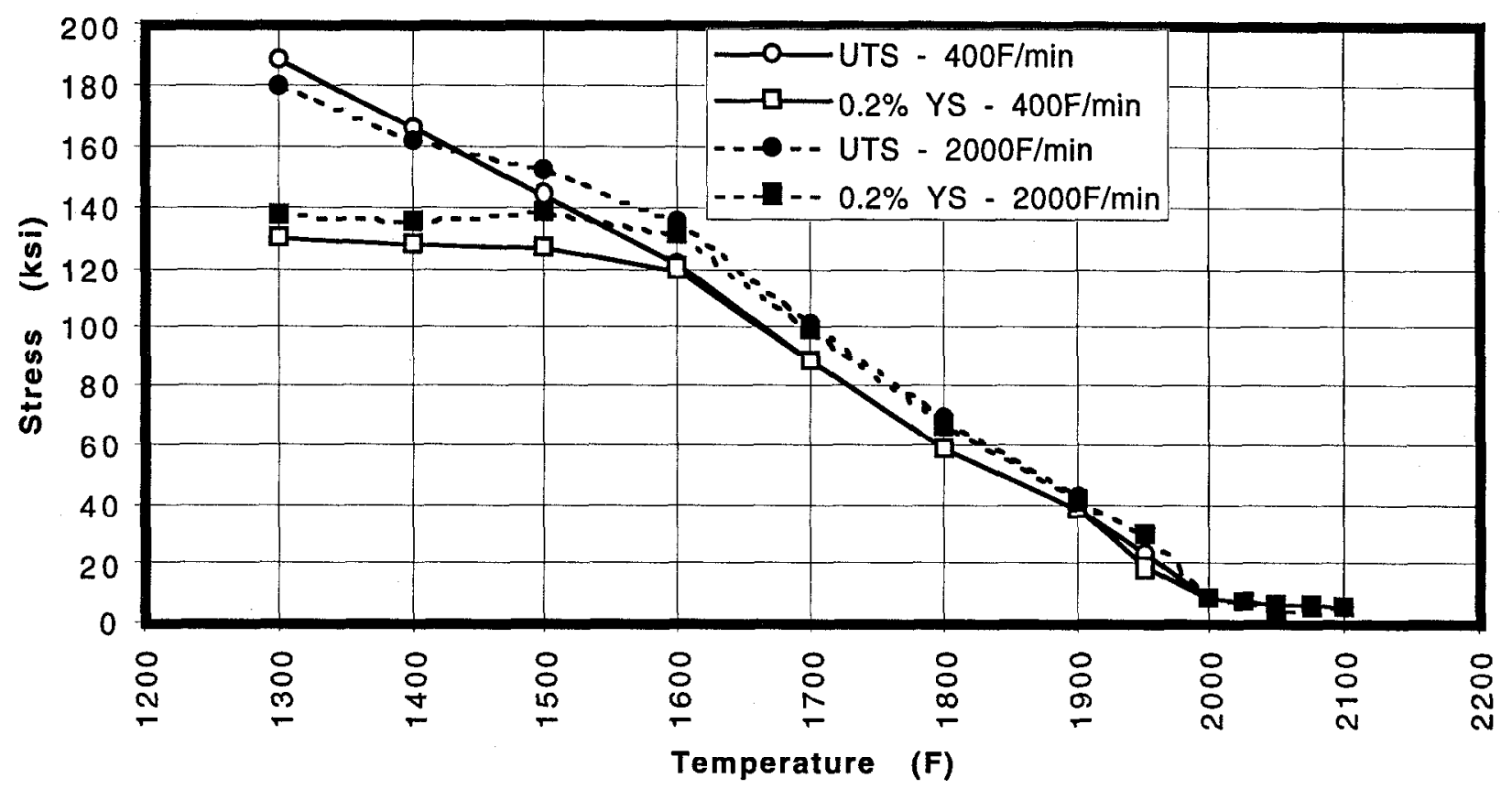

Figure 4. On-Cooling Tensile \% Elongation

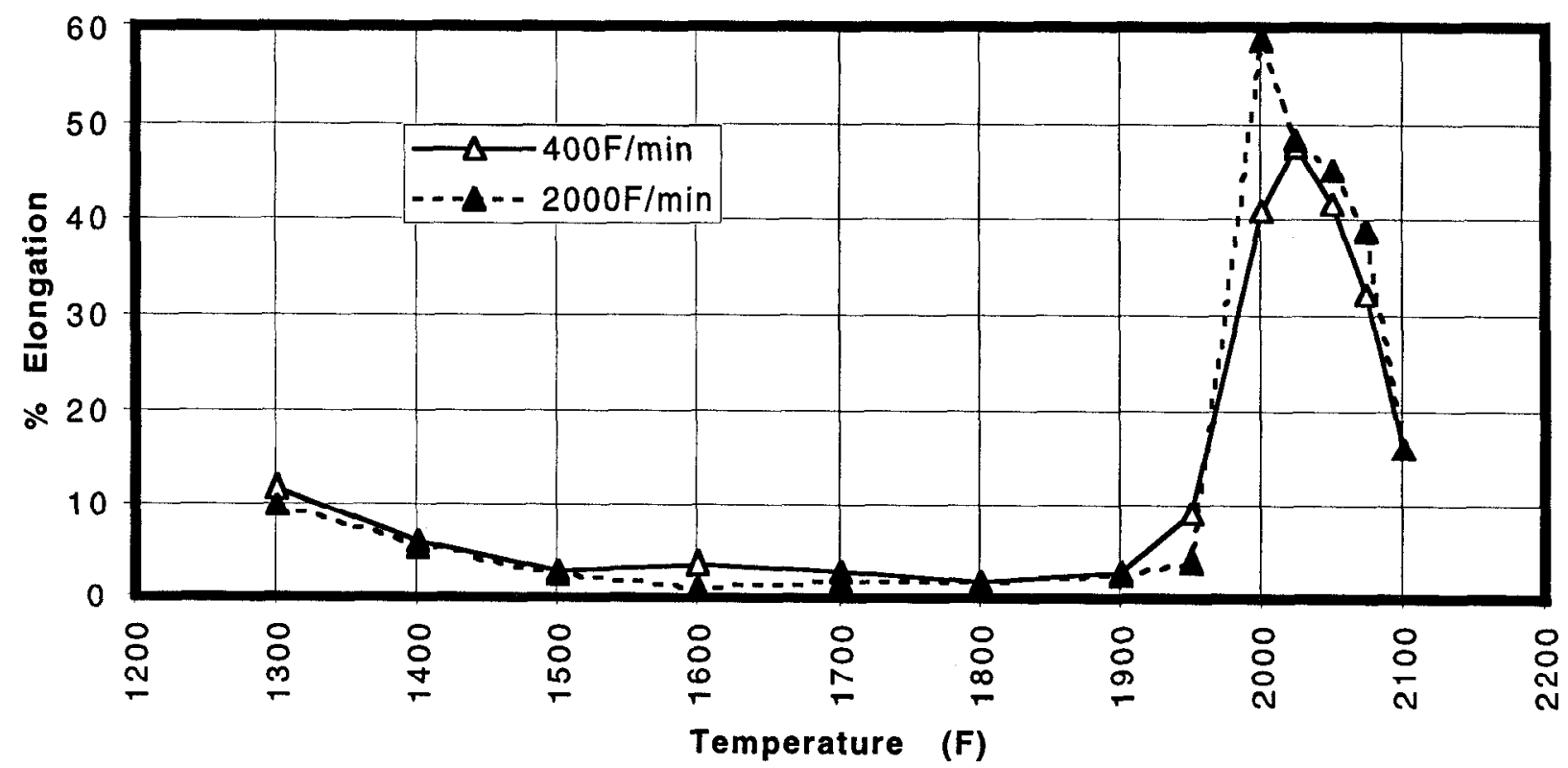



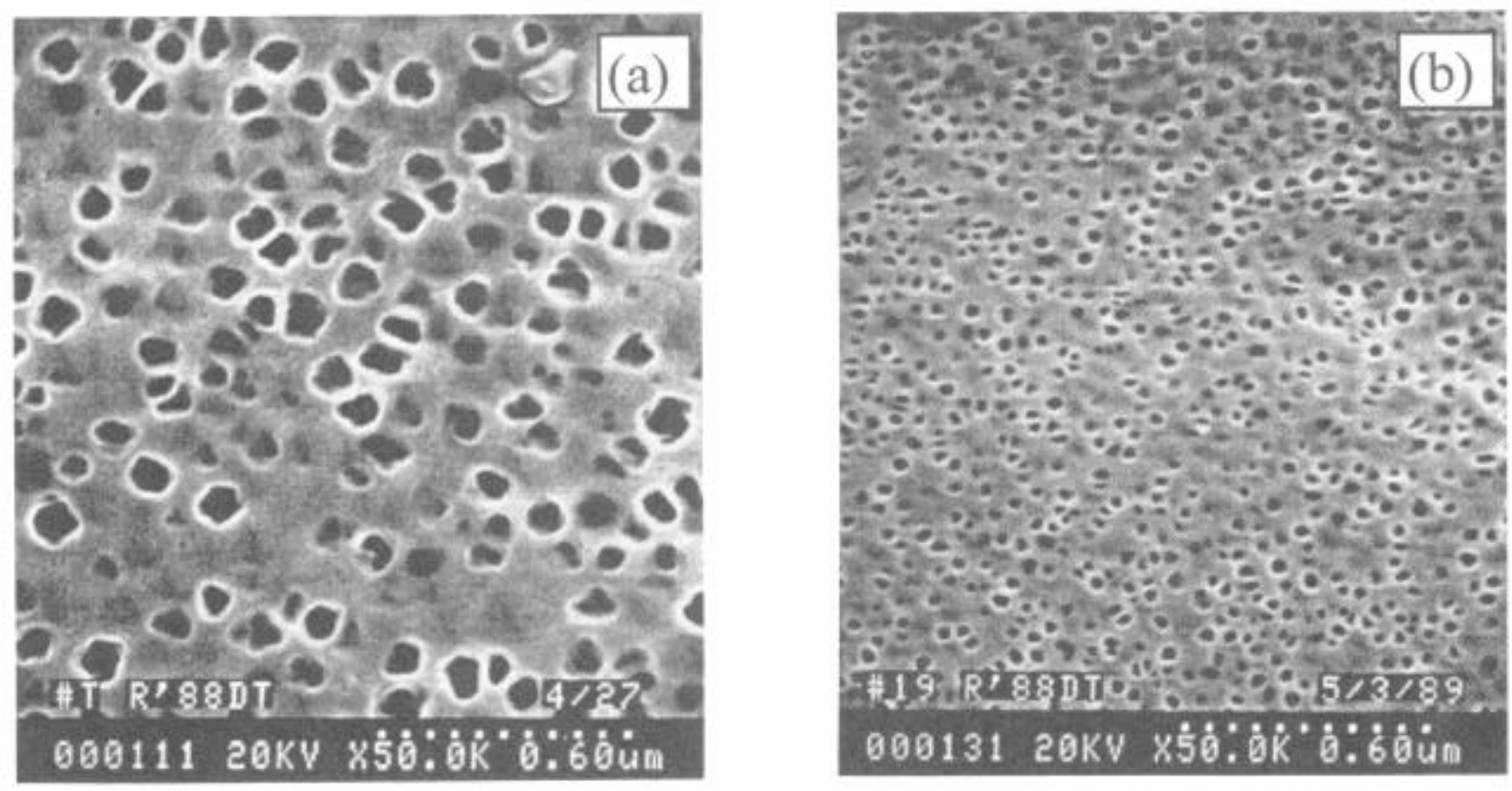

Figure 5. SEM micrographs of gamma prime precipitates from specimens tested at $1500^{\circ} \mathrm{F}$ (a) $400^{\circ} \mathrm{F} / \mathrm{min}$, (b) $2000^{\circ} \mathrm{F} / \mathrm{min}$.

gamma prime. For the $2000^{\circ} \mathrm{F}$ tests, the cooling rate did not affect gamma prime size because the stabilization time at a temperature only $30^{\circ} \mathrm{F}$ below the gamma prime solvus was sufficient to normalize any microstructural differences attributed to the differences in cooling rate from $2100^{\circ} \mathrm{F}$ to $2000^{\circ} \mathrm{F}$.

\section{Two-Step Cooling Path}

Microstructure. Optical and TEM replica micrographs are shown for heat treatments A, B, C and D in Figures 6 and 7. Differences in cooling rates and transition temperatures significantly affected the cooling gamma prime size and distribution. In general, the size of the cooling gamma prime increased in order of heat treatments A, C, B, and D. The largest precipitates correlated with a slower initial cooling rate and lower transition temperature (D), and the smallest precipitates correlated with the faster initial cooling rate and higher transition temperature (A).

Meehanical Properties. Tensile, creep and FCG properties are given in Tables II-IV and Figures 8-10, respectively. Duplicate tensile and creep tests were performed for each heat treatment.

Table II.

$1200^{\circ}$ F Tensile Properties

\begin{tabular}{|c|c|c|c|c|}
\hline $\begin{array}{c}\text { Heat } \\
\text { Treatment }\end{array}$ & $\begin{array}{c}0.2 \% \\
\text { Yield Strength } \\
\text { (ksi) }\end{array}$ & $\begin{array}{c}\text { Ultimate } \\
\text { Tensile Strength } \\
(\mathrm{ksi})\end{array}$ & $\begin{array}{c}\text { Elongation } \\
(\%)\end{array}$ & $\begin{array}{c}\text { Reduction } \\
\text { of Area } \\
(\%)\end{array}$ \\
\hline \multirow{2}{*}{ A } & 153.4 & 224.0 & 17 & 20 \\
& 153.6 & 224.0 & 19 & 20 \\
B & 136.9 & 216.9 & 19 & 20 \\
& 137.3 & 211.0 & 23 & 27 \\
C & 150.9 & 222.9 & 16 & 17 \\
& 153.4 & 223.2 & 18 & 20 \\
D & 134.0 & 210.0 & 23 & 25 \\
& 141.5 & 214.3 & 21 & 24 \\
\hline
\end{tabular}

FCG data represent FCG rates measured from single tests at a $\triangle K$ of 30 ksivinch for each heat treatment. SEM micrographs of fracture surfaces from $1200^{\circ} \mathrm{F} / 20 \mathrm{cpm}$ and $1200^{\circ} \mathrm{F} / 90$ second hold specimens given heat treatment $\mathrm{A}$ are shown in Figure 11. Both micrographs were taken in locations where $\Delta \mathrm{K}$ was approximately $25 \mathrm{ksi}$ inch.

\section{Discussion}

On-Cooling Tensile Data

Effect of Cooling Rate on On-Cooling Tensile Properties.

Comparisons of $400^{\circ} \mathrm{F} /$ minute and $2000^{\circ} \mathrm{F} /$ minute UTS and $0.2 \%$ yield stresses (YS) are shown in Figure 3. At $2000^{\circ} \mathrm{F}$ and above,

Table III.

$1200^{\circ}$ F / 123ksi Creep Properties

\begin{tabular}{|c|c|c|}
\hline $\begin{array}{c}\text { Heat } \\
\text { Treatment }\end{array}$ & $\begin{array}{c}\text { Time to } \\
\mathbf{0 . 2 \%} \text { Strain } \\
\text { (hours) }\end{array}$ & $\begin{array}{c}\text { Minimum } \\
\text { Creep Rate } \\
\text { (sec-1 } \times \text { E-10) }\end{array}$ \\
\hline A & $\begin{array}{c}225(1) \\
1090\end{array}$ & 2.8 \\
& 255 & 3.5 \\
B & 255 & 17.5 \\
& 795 & 6.9 \\
C & $(2)$ & 2.1 \\
& 440 & 0.75 \\
D & 300 & 6.5 \\
\hline
\end{tabular}

(1) Specimen A2 exhibited an unusually large amount of primary creep strain $(0.15 \%)$ compared to all other specimens in this study.

(2) Test discontinued at 1,316 hours before reaching $0.2 \%$ creep strain 
Table IV.

Fatigue Crack Growth Rates at $\Delta K=30$ ksivineh (inch/cycle $\times$ E-6)

\begin{tabular}{|c|c|c|c|}
\hline $\begin{array}{c}\text { Heat } \\
\text { Treatment }\end{array}$ & $\begin{array}{c}750^{\circ} \mathrm{F} \\
20 \mathrm{cpm}\end{array}$ & $\begin{array}{c}1200^{\circ} \mathrm{F} \\
20 \mathrm{cpm}\end{array}$ & $\begin{array}{c}1200^{\circ} \mathrm{F} \\
\text { 90 Second Hold }\end{array}$ \\
\hline A & 8.96 & 26.7 & 297 \\
B & 9.28 & 35.0 & 94.8 \\
C & 8.36 & 30.3 & 620 \\
D & 10.1 & 32.1 & 153 \\
\hline
\end{tabular}

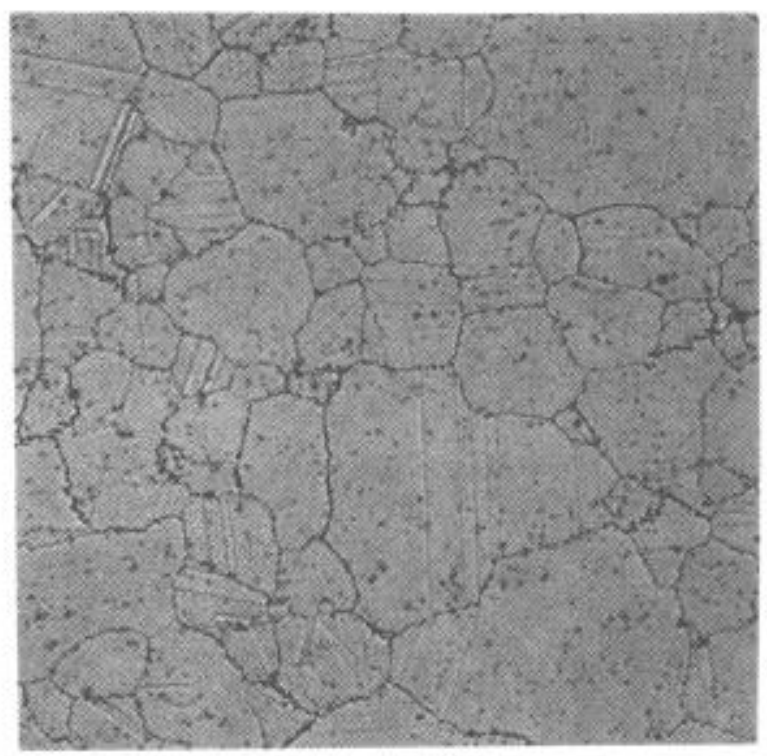

$\mathbf{5 0} \mu \mathbf{m}$

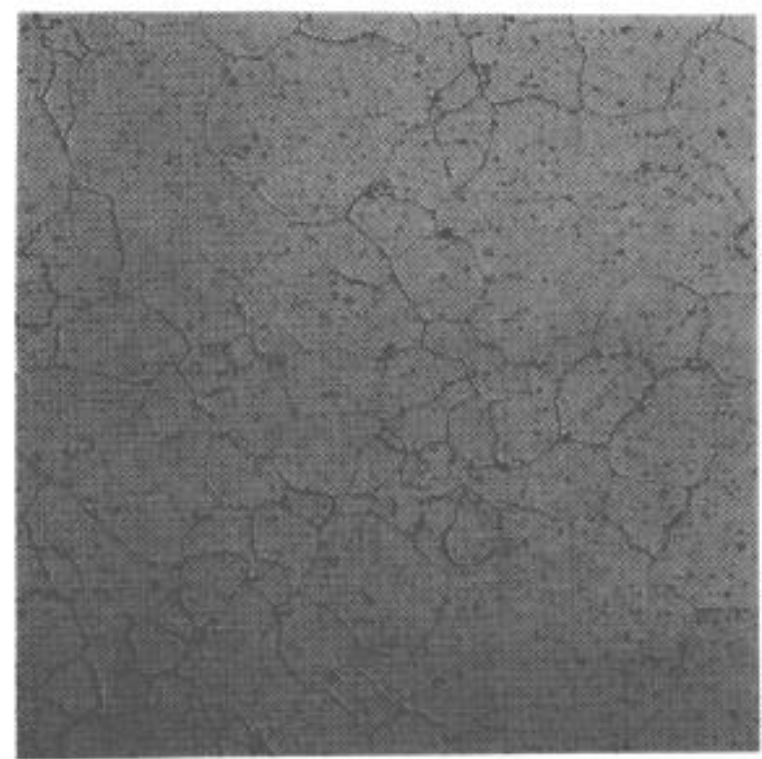

UTS and YS were not sensitive to cooling rate. This observation is in agreement with the previous description of similar gamma prime morphologies for the two different cooling rates when tested at $2000^{\circ} \mathrm{F}$. Below $2000^{\circ} \mathrm{F}$, the faster cooling rate generally produced a higher UTS and YS. Significant differences in UTS and YS for a given cooling rate were not seen until test temperatures were $1500^{\circ} \mathrm{F}$ and lower. A crossover in UTS occurted between $1400^{\circ} \mathrm{F}$ and $1500^{\circ} \mathrm{F}$, where the $400^{\circ} \mathrm{F} /$ minute UTS exceeded the $2000^{\circ} \mathrm{F} /$ minute UTS. It is not known why the cross-over in UTS occurred since all other tensile properties (YS, ductilities, and grain size) behaved in a predictable manner. Percent elongation is shown in Figure 4, Both cooling rates showed similar trends. Maximum elongation occurred at $2000^{\circ} \mathrm{F}-2025^{\circ} \mathrm{F}$. A dramatic reduction in clongation occurred at temperatures above and below $2000-2025^{\circ} \mathrm{F}$. The nil ductility temperature was estimated to be
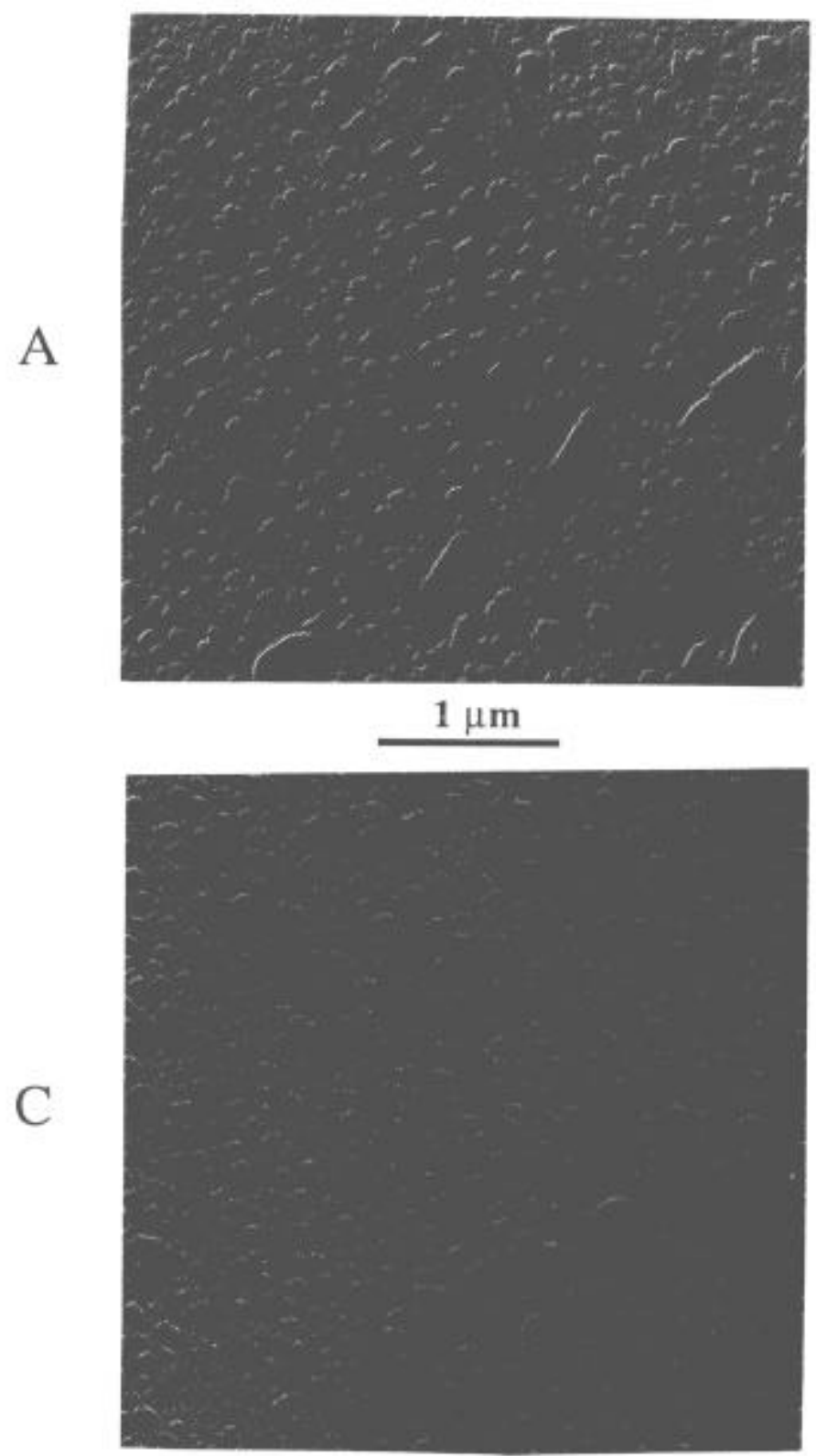

Figure 6. Optical (50X) and TEM replica $(20,000 \mathrm{X})$ micrographs of heat treatments $\mathrm{A}$ and $\mathrm{C}\left(2000^{\circ} \mathrm{F}\right.$ transition temperature). 
about $2120^{\circ} \mathrm{F}$. There was a ductility trough in the temperature range of $1500-1900^{\circ} \mathrm{F}$, where the average percent elongation was $2.5 \%$. Ductilities did not begin to increase until $1400^{\circ} \mathrm{F}$. The $2000^{\circ} \mathrm{F} /$ minute tests showed generally higher ductilities at temperature greater than $2000^{\circ} \mathrm{F}$, but lower ductilities at temperatures less than $1950^{\circ} \mathrm{F}$, when compared to the $400^{\circ} \mathrm{F} /$ minute data.

It was not surprising to see very large grains (ASTM 3.0-5.5) in the $400^{\circ} \mathrm{F} /$ minute specimens tested at $2075^{\circ} \mathrm{F}$ and $2100^{\circ} \mathrm{F}$. These temperatures are above the gamma prime solvus and would allow dynamic grain growth to occur similarly to grain growth observed in Udimet 720 deformed at a slow strain rate at a supersolvus temperature (6). The grain growth was probably localized which would help to explain why large grains were seen in the $400^{\circ}$ F/minute specimens but

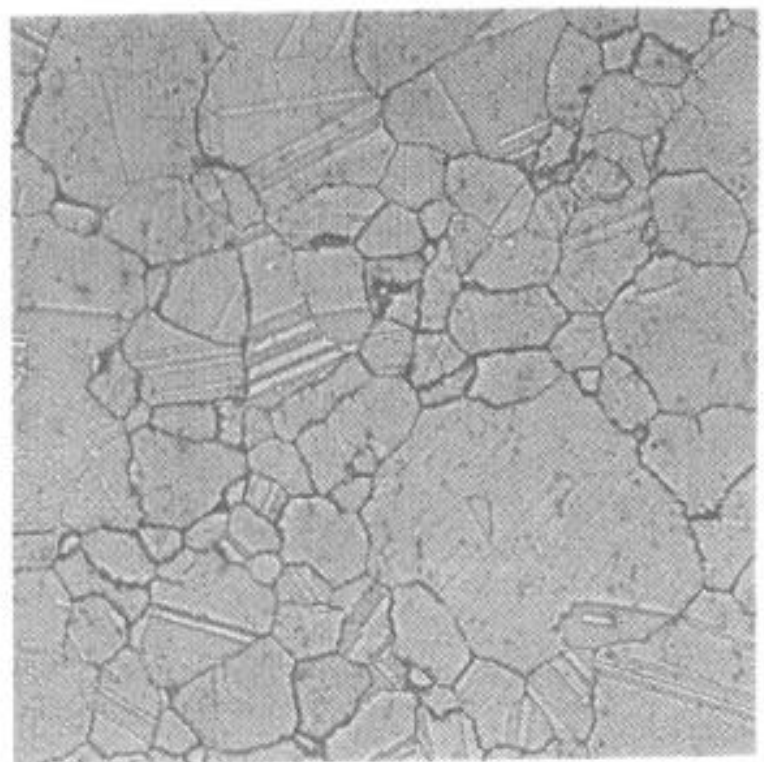

$50 \mu \mathrm{m}$

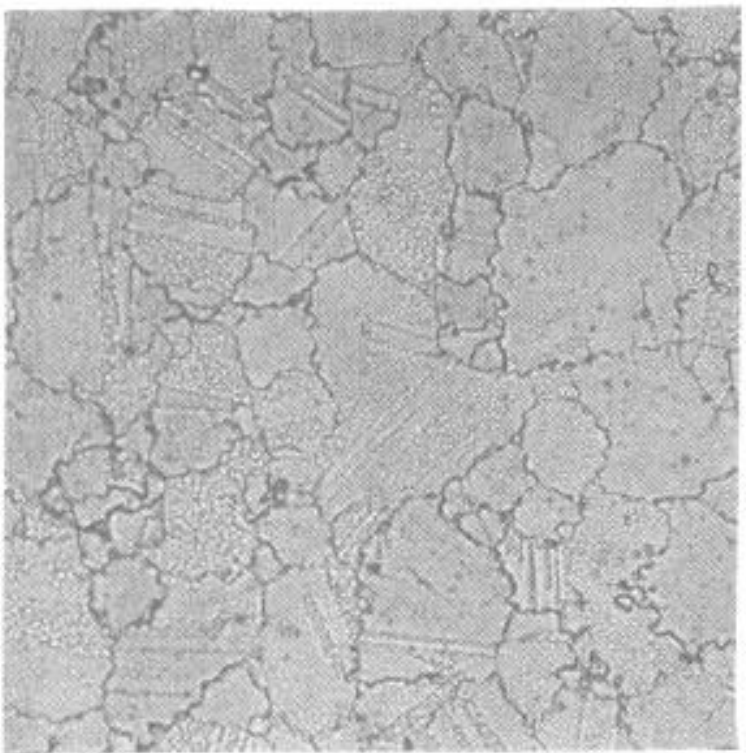

not seen in the $2000^{\circ} \mathrm{F} /$ minute specimens.

The on-cooling tensile data can be utilized by finite element models to predict thermally induced stresses and displacements. The approach allows the engineer to manage thermally induced stresses via a computer model, and to vary heat treatment parameters and/or forging geometries to keep local stresses from exceeding the failure criterion, c.g. UTS. Additional data not shown, but easily available from the test, include Young's Modulus and load vs. displacement curves at each test temperature. The on-cooling data, coupled with appropriate thermal/stress models, have successfully modeled the heat treatment of Rene'88DT forgings to preclude quench cracking, thereby reducing production problems and accompanying costs (4).

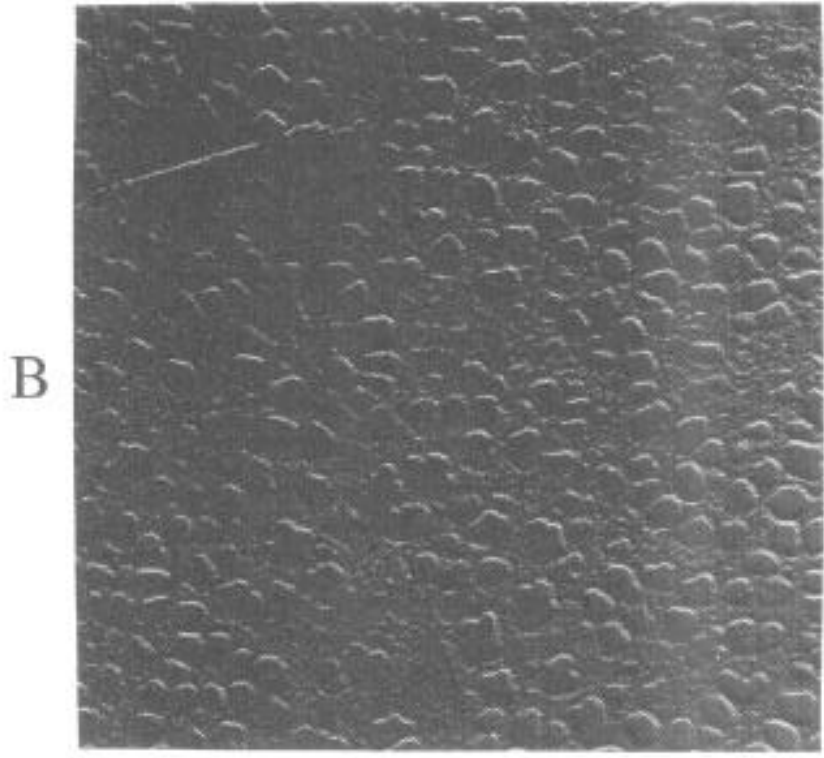

$1 \mu \mathrm{m}$

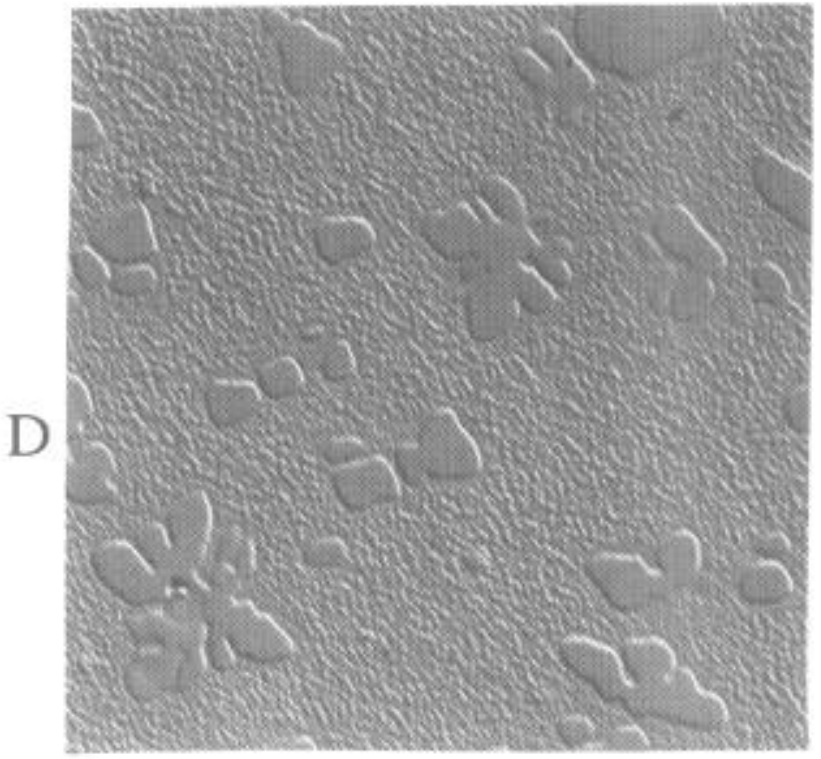

Figure 7. Optical (50X) and TEM replica $(20,000 \mathrm{X})$ micrographs of heat treatments B and D (1900'F transition temperature). 
Fig. 8 - 1200F Tensile Data

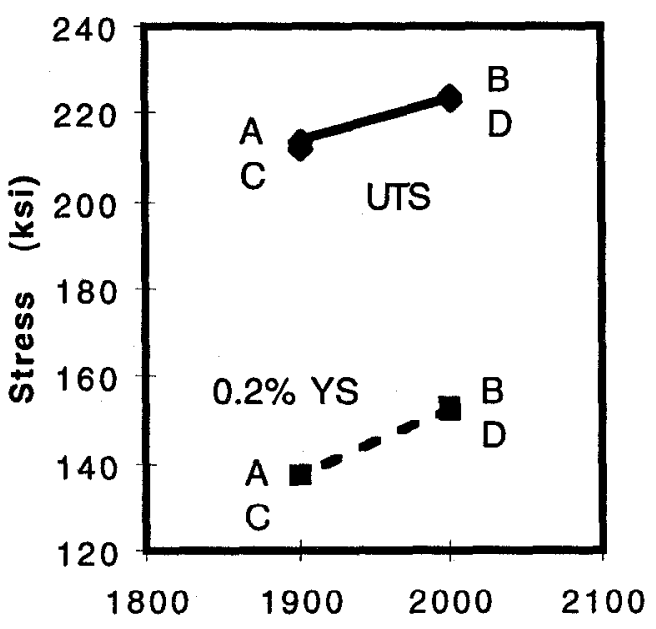

Transition Temperature (F)

Fig. 9 - Minimum Creep Rate

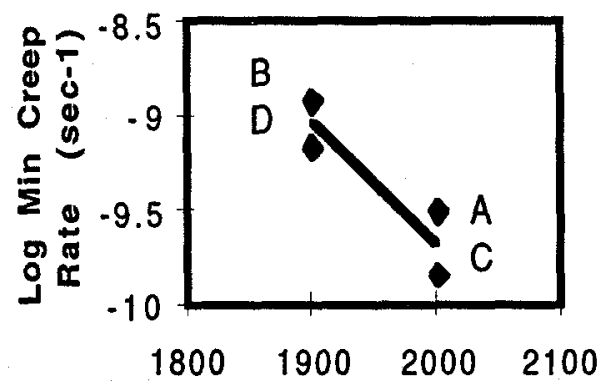

Transition Temperature (F)

\section{Two-Step Cooling Path}

Tensile, creep and FCG data are plotted as a function of transition temperature in Figures 8-10. Tensile strengths and minimum creep rates were not sensitive to the first step cooling rate, as noted by similar mechanical property values for heat treatment pairs $A\left(30^{\circ} \mathrm{F} /\right.$ minute) and $\mathrm{C}\left(7^{\circ} \mathrm{F} /\right.$ minute), and $\mathrm{B}\left(30^{\circ} \mathrm{F} /\right.$ minute $)$ and $\mathrm{D}\left(7^{\circ} \mathrm{F} /\right.$ minute $)$. It was interesting to note that while heat treatments $B$ and D had similar mechanical properties, their cooling gamma prime sizes and distributions were very different. The most important heat treatment variable was the transition temperature. Tensile strengths increased, and minimum creep rates decreased, as the transition temperature increased from $1900^{\circ} \mathrm{F}$ to $2000^{\circ} \mathrm{F}$. The FCG data showed mixed behavior as a function of transition temperature. $20 \mathrm{cpm}$ data showed a slight decrease in crack growth rates as the transition temperature increased; however, the $1200^{\circ} \mathrm{F} / 90$ second hold time crack growth rates showed a significant increase (24X) compared to the $1200^{\circ} \mathrm{F} / 20 \mathrm{cpm}$ data. The slower hold time crack growth rates for the $1900^{\circ} \mathrm{F}$ transition temperature were attributed to the higher creep rates. The higher creep rates allowed for significant stress relaxation at the crack tip, thereby lowering the effective stress concentration at the crack tip.

\section{Fig. 10 - Fatigue Crack Growth}

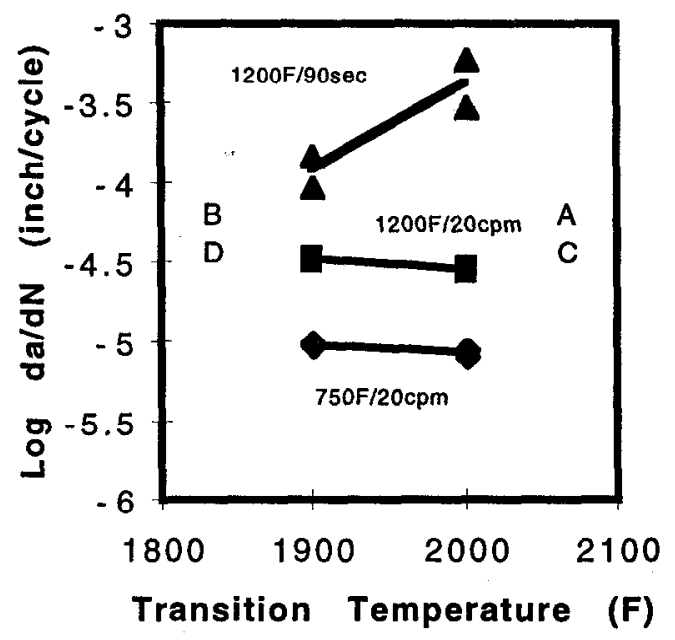

All $20 \mathrm{cpm}$ fracture surfaces at $750^{\circ} \mathrm{F}$ and $1200^{\circ} \mathrm{F}$ showed predominately transgranular fracture paths. $1200^{\circ} \mathrm{F} / 90$ second hold surfaces were predominately intergranular, with a slight increase in transgranular behavior moving from heat treatment $A$ to $D$. Hold time facet texture became coarser from $A$ to $D$ because of the larger gamma prime precipitates that formed at grain boundarics for the slower cooling rates. Examples of $1200^{\circ} \mathrm{F} / 20 \mathrm{cpm}$ and $1200^{\circ} \mathrm{F} / 90$ second hold fracture surfaces for heat treatment $\mathrm{A}$ are shown in Figure 11.

The nucleation and growth of gamma prime during the quenching of a disk from a supersolvus solution temperature is a complex process which is difficult to model, especially in regions that cool slowly (7). Yet these regions can be critical to the function of the component, e.g. tensile strength in the thick bore section of a turbine disk. Rather than heat treat and evaluate an entire forging, the approach outlined for the two-step cooling path evaluation could be used to save considerable time and cost during the design and manufacture of a new disk forging. For example, one could determine via a thermal model the shape of local cooling curves at critical locations in the disk. Coupons could then be solutioned and cooled to duplicate the predicted cooling curves. Mechanical properties from the coupons would represent approximate values expected from full scale hardware. Trade studies could also be performed based on the engineering requirements for a given region in a disk. For example, if hold time crack growth was considered to be important, then the engineer would be able to quantify the reductions in tensile and creep strengths which resulted when a desired hold time crack growth rate was achieved.

\section{Conclusions}

\section{On-Cuoling Tensile Test}

i. The on-cooling tensile test is an excellent method to determine strength and ductility data for input to finite element models, although care must be taken to assure accurate pyrometer temperature measurements during the test.

ii. Between $2000^{\circ} \mathrm{F}$ and $2100^{\circ} \mathrm{F}$, Rene' $88 \mathrm{DT}$ UTS and YS were relatively insensitive to temperature. Below $2000^{\circ} \mathrm{F}$, tensile strength increased rapidly. 


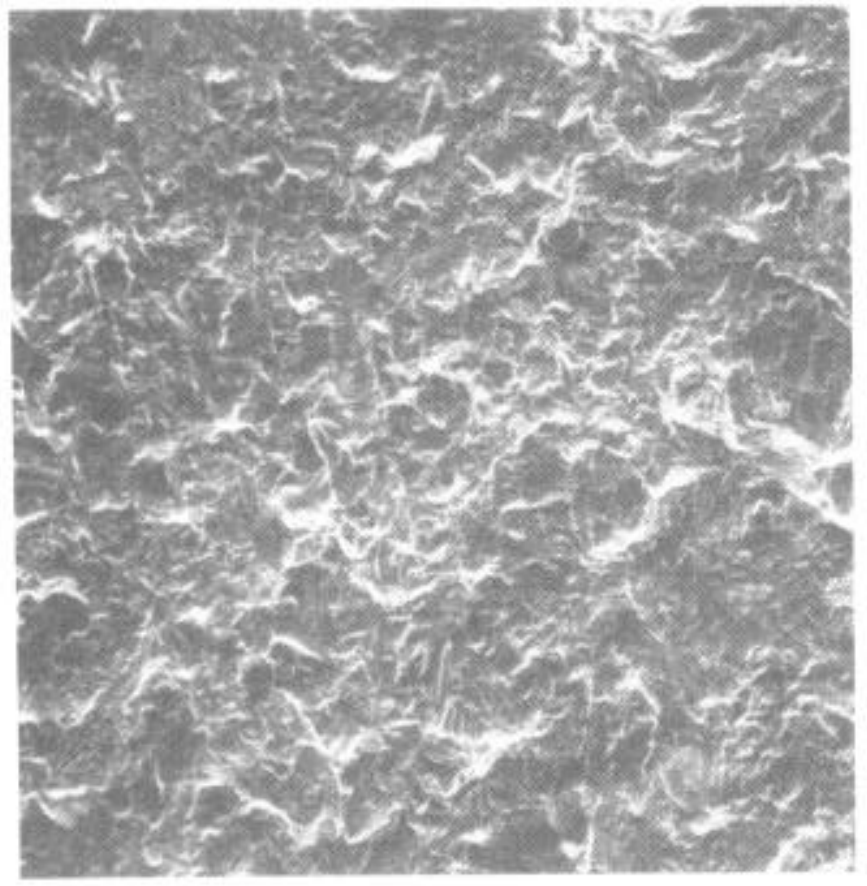

(a)

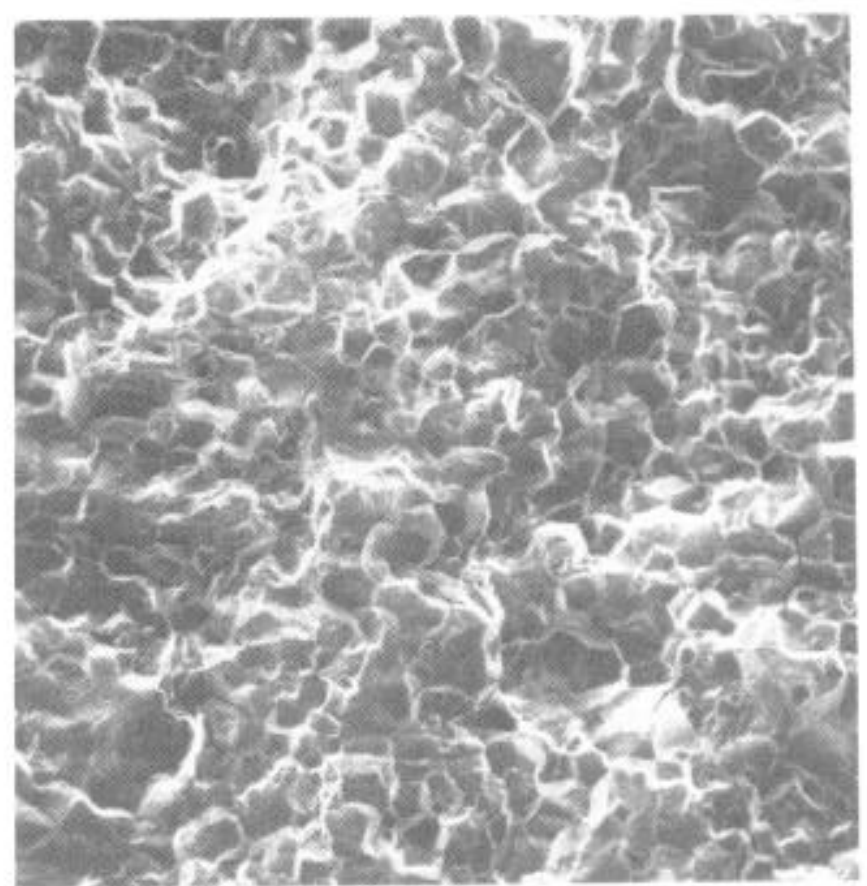

(b)

Figure 11. SEM micrographs of fracture surfaces from fatigue crack growth specimens (a) $1200^{\circ} \mathrm{F} / 20 \mathrm{cpm}$, (b) $1200^{\circ} \mathrm{F} / 90 \mathrm{sec}$.

\section{Referencès}

iii. Percent elongation was highest at $2000-2025^{\circ} \mathrm{F}$. At higher and lower temperatures, ductilities dropped precipitously. The nil ductility temperature was estimated to be about $2120^{\circ} \mathrm{F}$, Between $1900^{\circ} \mathrm{F}$ and $1500^{\circ} \mathrm{F}$, a ductility trough existed, where percent elongation values averaged $2.5 \%$. Below $1500^{\circ} \mathrm{F}$, ductilities began to increase

iv. On-cooling tensile data, in conjunction with thermal/stress models, have been used to successfully model the heat treatment process to preclude quench cracking of Rene' 88DT forgings (see Ref. 4).

\section{Two-Step Cooling Path}

i. For the two-step cooling curves evaluated in this study, the transition temperature was found to be more important in determining mechanical properties than was the initial cooling rate.

ii. A higher transition temperature correlated with better tensile and creep/rupture properties and faster hold time fatigue crack growth rates.

iii. The approach outlined for the two-step cooling path technique can be applied to the evaluation of turbine components. Significant reductions in time and cost can be achieved by evaluating coupons heat treated to predicted cooling curves at critical locations in the full scale hardware

\section{Acknowledgments}

The author acknowledges Mr. Ronald Tolbert and Mr. Thomas Daniels for their teclunical support of the work described in this publication.
(1) T.T. King, et al., "USAF Engine Damage Tolerance Requirements," AIAA-85-1209, 1985.

(2) D.D. Krueger, R.D. Kissinger and R.G. Menzies, "Development and Introduction of a Damage Tolerant High Temperature Nickel Base Disk Alloy, Rene'88DT," Superalloys 1992, S.D. Antolovich, et al., eds, TMS-AIME, 1992, pp. 277-286.

(3) R.A. Wallis and P.R. Bhowal, "Property Optimization in Superalloys through the Use of Heat Treatment Modeling," Superalloys 1988, D.N. Duhl et al., eds. TMS-AIME, 1988, pp, 525-534.

(4) R.1. Ramakrishnan and T.E. Howson, "Modeling the Heat Treatment of Superalloys," JOM (June, 1992) pp. 29-32

(5) Metcut Research Associates, Inc. Job $\# 100-48042$, W.J. Stross and M. J. Booker.

(6) J.M. Hyzak, R.P. Singh, J.E. Morra and T.E. Howson, "The Microstructural Response of As-HIP P/M U720 to Thermomechanical Processing." Superalloys 1992, S.D. Antolovich et al., eds., TMS-AIME, 1992, pp. 93-102.

(7) J.J. Schirra and S.H Goetschius, "Development of an Analytical Model Predicting Microstructure and Properties Resulting from the Thermal Processing of a Wrought Powder Nickel-Base Superalloy Component," Superalloys 1992, S.D. Antolovich et al., eds., TMS-AIME, 1992 , pp. 437-446. 